\title{
GEOGRAPHY OF NATURAL AND RECREATIONAL FACILITIES IN THE DEVELOPMENT OF ECONOMIC INTEGRATION OF THE BORDER AREAS OF NORTHERN KAZAKHSTAN AND THE RUSSIAN FEDERATION
}

\author{
Aigerim SANSYZBAYEVA* \\ L.N. Gumilyov Eurasian National University, Faculty of Natural Sciences, Nur-Sultan, Kazakhstan, e-mail: sansyzbayeva.ab@mail.ru
}

\author{
Abdimazhit SAIPOV
}

L.N. Gumilyov Eurasian National University, Faculty of Natural Sciences, Nur-Sultan, Kazakhstan, e-mail: saipov1954@mail.ru

\author{
Aleksandr DUNETS \\ Altai State University, Department of Economic Geography and Cartography, 61a Pr.Lenina, Barnaul, Russia, e-mail: dunets@mail.ru
}

\begin{abstract}
Aizhan MUSSAGALIYEVA
Al-Farabi Kazakh National University, Department of Geography, Land Management and Cadastre, Almaty, Kazakhstan, e-mail: mussagaliyeva_a@mail.ru
\end{abstract} Ainash RAMAZAN
Al-Farabi Kazakh National University, Department of Recreation Geography and Tourism, Almaty, Kazakhstan, e-mail: ramazanainash@gmail.com
Citation: Sansyzbayeva, A., Saipov, A., Dunets, A., Mussagaliyeva, A., \& Ramazan, A. (2021). GEOGRAPHY OF NATURAL AND RECREATIONAL FACILITIES IN THE DEVELOPMENT OF ECONOMIC INTEGRATION OF THE BORDER AREAS OF NORTHERN KAZAKHSTAN AND THE RUSSIAN FEDERATION. GeoJournal of Tourism and Geosites, 35(2), 499-506. https://doi.org/10.30892/gtg.35230-677

\begin{abstract}
This study presents the natural and recreational prerequisites for the formation and development of the cross-border tourism industry in the Kazakh-Russian border region in the context of modern integration processes. The purpose of the research is to identify the main natural and recreational resources in the border regions of Northern Kazakhstan, among which the border regions are Kostanay, Pavlodar and North Kazakhstan regions, and the constituent entities of the Russian Federation bordering on them. The scientific significance of the article is determined by the fact that it analyzes the natural and recreational resources of 10 regions of the Kazakh-Russian borderland as a basis for the formation and development of joint tourist destinations. The main research method is a spatial analysis of the location of natural and recreational resources of border areas using modern soft ware, as a result of which maps of natural and recreational resources in the study area were compiled. In the course of the study, it was revealed that the Pavlodar and North Kazakhstan regions of the Republic of Kazakhstan and the Altai Krai, Novosibirsk and Omsk regions of the Russian Federation have the greatest potential for the development of cross-border tourism.
\end{abstract}

Key words: cross-border tourism, border area, economic integration, Kazakh-Russian border area, Northern Kazakhstan

$* * * * * *$

\section{INTRODUCTION}

In the era of globalization, the dominant trend of world development is regional integration, which results in an intensive exchange of goods, services, capital and labor resources. One of the types of services that, in turn, strengthen integration processes, being one of the factors of economic integration, are tourist services and a special category of the tourism industry is tourism of "border areas", since the development of this type of tourism is determined by the nature of border processes, sociocultural relations and trade and economic relations. The mutual location of such large States as Kazakhstan and Russia in the common economic space of the Customs Union, the presence of the longest land state border between the countries, the common historical, cultural and socio-economic development, modern integration processes and a political strategy aimed at expanding and deepening these processes contribute to the stable development of the tourism sector of the economy. Although the current epidemiological situation in the world and regions hinders the further development of tourism, but the right to tourism remains with people. Therefore, the further development of tourism is certain, but requires adaptive measures in the context of modern changes. In the conditions of economic integration of countries, so-called cross-border tourist territories are formed. This is a territorial entity consisting of two or more neighboring or closely located countries or their regions that have a mutual interest and desire for the development of international tourism (Grudinin, 2016).

Geographical problems of studying the tourist and recreational space are the most important area of work of recreational geography - the search and evaluation of territories that are promising for the development of the recreation industry, sports, and recreation. In this respect, the cross-border area has a special perspective and value (Evstropyeva, 2009). Supporting the global trend of integration of border areas of neighboring States (for example, Euroregions) in the Russian-Kazakh crossborder region, the search for ways and forms of cooperation for the formation of joint economic structures that allow 
developing border economies and implementing common projects is underway (Sereda, 2014). Most often, cross-border territories are formed on the basis of a common tourist resource - a common natural or historical and cultural heritage, the joint use of which becomes more attractive for tourists and more beneficial for participants in such cooperation. Thus, these countries gain competitive advantages over regions that do not participate in cooperation with foreign neighbors (Soldatenko, 2015). The economy and attractiveness of commercial tourism in the border regions, the establishment of relations between neighboring countries, families and people living in the border regions are also the engines of socio-economic development (Sharifzadeh Aghdam et al., 2020). Despite the important role of cross-border tourism cooperation, this is hindered by problems associated with differences between states and border territories (Dunets et al., 2019) and tourism can also become one of the mechanisms for starting the development of cross-border cooperation with the subsequent transformation into a diversified economic center due to the multiplier effect and favorable investment climate (Korneevets et al., 2019).

Geographical proximity, trade, economic and humanitarian ties, technological production and enterprises with developed infrastructure strengthen the importance of cross-border cooperation (Sansyzbayeva et al., 2020). Models of cross-border territorial systems can serve as guidelines for defining strategies for cross-border cooperation (Ilieş et al., 2011). Cross-border tourism is an important tool for the harmonization of interethnic relations (Karatabanov et al., 2020). Cross-border cooperation is of particular importance for stable regional development and integration. The development of cross-border relations and cooperation is an important tool for overcoming the negative consequences of the peripheral nature of border regions (for example, more than $70 \%$ of border subjects of the Russian Federation are considered depressed) (Korneevets et al., 2019).

Regional monitoring of domestic tourism is necessary for timely identification of problems and highlighting solutions that will accelerate its development. Assessment of the socio-economic efficiency of tourism using a set of indicators is very important and leads to the development of possible strategies for the development of inbound tourism as an economic direction. Indicators must meet certain requirements: an objective assessment based on statistical data, the elimination of duplicate data, data availability. As the aim of the study is to identify the main natural and recreational resources in the border regions of Northern Kazakhstan, among which the border regions are Kostanay, Pavlodar and North Kazakhstan regions, and the constituent entities of the Russian Federation bordering on them. In most cases, assessing the socioeconomic performance of tourism requires detailed data that are not fully available in emerging developing countries such as Kazakhstan, since they have not been included in national statistics. The indicators of the socio-economic development of this young country with 30 years of history, published mainly at the regional level, determine the limitations for a detailed analysis of the impact of tourism (Aliyeva et al., 2019a).

\section{MATERIALS AND METHODS}

The first study of the role of borders in tourism development was published abroad in the late 1970s in the work "Borders and tourism: fundamental connections" (Matznetter, 1979). This research topic was developed more widely in the 2000s. Using the approach of D. Matznetter, the American scientist Timothy (2001) in his monograph "Tourism and political borders" identified three types of interaction between borders and tourism: the border as a barrier, a tourist destination and a modifier of the tourist landscape. Hampton (2009) conducted a study on cross-border tourism in one of the economic growth triangles in ASEAN, which unites the border zones of three States-Singapore, Malaysia (Johor state) and Indonesia. In Russia and Kazakhstan, studies of cross-border territories and their interrelations have appeared relatively recently (Akhaev, 2019). The theoretical and methodological basis of the study is based on the methods and results of research by Western, Russian and domestic scientists in the field of socio-economic geography, tourism, economic integration and cross-border cooperation of regions. In the literature, the concepts of border territory have become increasingly used (Prescott, 1987; Vardomskiy, 1982; Fedorov et al., 2009; Baklanov, 2008, 2018; Katrovsky, 2017). The study of the Russian-Kazakh border in the border areas is devoted to the works of a number of scientists (Golunov, 2005; Bozhko, 2014, 2016). Russian and foreign researchers show great interest in the study of tourism in the border area (Więckowski, 2010; Stepanova, 2017; Ismagulova, 2019).

The theoretical aspects of studying the problem of the development of cross-border territories from the standpoint of geography, economics, ecology, politics and the search for options for their effective practical solution are in the field of view of scientists. The surge of interest in them was manifested with the emergence of the need to delineate the powers of the center and the subjects of the Russian Federation to deepen cross-border cooperation and solve environmental problems.

The regulatory framework of the study is based on agreements and agreements on cooperation between the two countries, which currently number about 400. The main ones are: The Treaty of friendship, cooperation and mutual assistance of 25.05.1992; the Treaty on further deepening of economic cooperation and integration of the Republic of Kazakhstan and the Russian Federation of 28.03.1994.; Declaration on eternal friendship and Alliance between the Republic of Kazakhstan and the Russian Federation, oriented to the XXI century, dated 06.07.1998. In early 2010, work began on the development of economic turnover of the Republic of Kazakhstan, the Russian Federation and the Republic of Belarus within the Customs Union. In September 2011, the program of long-term economic cooperation between the Government of the Russian Federation and the government of the Republic of Kazakhstan (until 2020) was signed. This study was conducted using the methods of comparative geographical analysis, cartographic method, processing of statistical data, official documents and literary sources, SWOT analysis etc. Spatial analysis and data synthesis were performed using the geographic information system ArcGIS 10.1 (Chashina, 2020). With the help of these research methods, data were collected on the presence and location of natural recreational objects and specially protected areas, on the basis of which the main tourist zones of the studied territories were determined. With the help of cartographic and comparative-geographical methods, territories with the highest natural reserve fund have been identified. As a result, the analysis of the location of natural and recreational resources was carried out and the regions with the most promising prerequisites for the development of integration processes in the field of tourism were identified (Issabayev et al., 2016). 


\section{STUDY OBJECT}

The study covers the border regions of Northern Kazakhstan and Russia, located along the state border. The length of the border between Kazakhstan and Russia $(7500 \mathrm{~km})$ is considered the longest land border in the world (Statistics Russia, 2018). Northern Kazakhstan borders on six regions (Orenburg, Chelyabinsk, Kurgan, Omsk, Tyumen, Novosibirsk) and the Altai Krai of Russia (Figure 1). Northern Kazakhstan is represented by 4 large administrative-territorial units: North Kazakhstan, Akmola, Kostanay, Pavlodar regions. But at the same time, according to this map, only 3 regions are bordering: North Kazakhstan, Kostanay, Pavlodar regions. Akmola region and the city of Nur-Sultan are not bordering, as being located in the central part of Kazakhstan, they do not border the Russian Federation. For Kazakhstan, which is an active participant in the integration processes, cross-border territories with neighboring states are of particular importance, since 12 out of 14 regions of the republic are border regions. In connection with the above, in the aspect of border regions, Akmola region and Nur-Sultan city are not considered in this study. The border regions of Northern Kazakhstan and Russia are presented in Table 1.

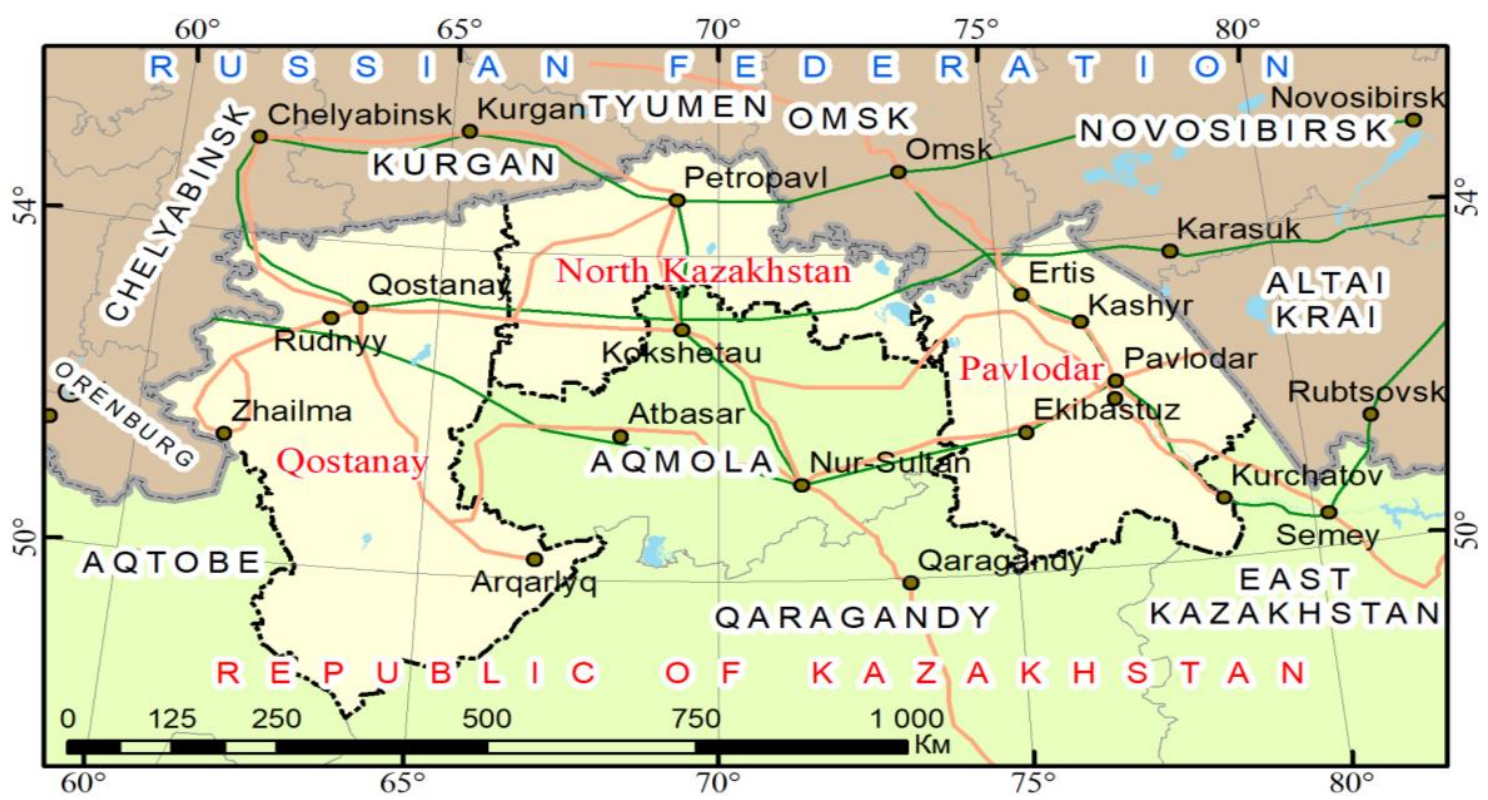

Figure 1. Border regions of Northern Kazakhstan and the Russian Federation

(Political and administrative map of the Russian Federation / Political map of the world, 2018)

\begin{tabular}{|c|c|c|}
\hline $\begin{array}{c}\text { Regions of Northern Kazakhstan bordering } \\
\text { with the subjects of the Russian Federation }\end{array}$ & $\begin{array}{c}\text { Subjects of the Russian Federation } \\
\text { bordering with Northern Kazakhstan }\end{array}$ & $\begin{array}{c}\text { Length of } \\
\text { the border }\end{array}$ \\
\hline North Kazakhstan region & Kurgan, Tyumen, Omsk regions & $1160 \mathrm{~km}$ \\
\hline Pavlodar region & Omsk, Novosibirsk region, Altai Krai & $978 \mathrm{~km}$ \\
\hline Kostanay region & Orenburg, Chelyabinsk, Kurgan regions & 1517 \\
\hline
\end{tabular}

Table 1. Regions of Northern Kazakhstan and border regions of the Russian Federation (Mazhitova et al., 2020)

\section{RESULTS DISCUSSIONS}

Tourism, being a segment of the economy, on the one hand, forces border regions to compete and on the other - contributes to the strengthening of cooperation in the cross-border region. The border regions of different countries are competitors in attracting tourists, but cooperation is possible between them in order to fully use the tourist and recreational potential and effectively organize cross-border routes. Thus, the cooperation of tourist organizations and management bodies of these territories allows you to get competitive advantages in comparison with other regions that are more remote from the border. Cross-border cooperation is a natural function of border areas and one of the main factors of their development. Cooperation in the field of tourism and the involvement of integration partners in joint innovative projects for the development of communications and the use of the natural resource potential of the participating countries is possible only with mutually beneficial cooperation and the interest of both parties. Russia and Kazakhstan have all the necessary prerequisites to become an example of close cooperation in the field of tourism, this is facilitated by the following areas:

- international meetings where the further development of the tourism sector of the Russian Federation and the Republic of Kazakhstan is discussed;

- creation of tourist infrastructure facilities on transport routes;

- development of rural areas in order to promote rural and agricultural tourism, as well as folk crafts and souvenirs;

- development of ecological tourism in specially protected natural areas;

- mutual simplification of the visa regime and visa formalities for tourists, implementation of visa-free tourist exchange;

- implementation of measures to support small and medium-sized businesses in the field of tourism, culture, folk crafts, souvenirs and etc (Aliyeva et al., 2019b).

Also, one of the factors in the development of interethnic tourism in border areas is "price discrimination", this is when different prices are indicated for the same product in different places. A number of products are cheaper to buy in Kazakhstan 
than in Russia. Tourists are attracted to the border area by duty-free trade, a large selection of goods, and lower prices. Another significant factor in the development of tourism in border areas is the availability of unique tourist resources, which can be explored when traveling from the border area of a neighboring country. For example, residents of the Pavlodar region often come to Lake Yarovoe, the resort of Belokurikha, which are located in the Altai Krai. In addition, tourists from Kazakhstan are increasingly attracted to Siberian ski resorts (Shumkina, 2015). The basis of the recreational potential of the territory and the development of the tourism industry is the natural and recreational resources of the territory, which, having a certain degree of tourist attraction, serve as ways to attract tourists and recreants (Kropinova et al., 2020).

Table 2. Natural and recreational resources of the border regions of the Republic of Kazakhstan and the Russian Federation (collected by author)

\begin{tabular}{|c|c|c|c|c|c|}
\hline \multicolumn{3}{|c|}{$\begin{array}{l}\text { KAZAKHSTAN } \\
\end{array}$} & \multicolumn{3}{|c|}{ RUSSIA } \\
\hline \multicolumn{2}{|r|}{ Recreational facilities } & \multirow[b]{2}{*}{\begin{tabular}{|c|} 
Specially protected areas \\
Nauruzum nature \\
reserve, Altyn Dala \\
reserve, 3 nature reserves \\
(Tounsor, Zharsor- \\
Urkash, Mikhailov), 10 \\
natural monuments \\
("Tract Stone lake", \\
"Olshanniki", etc.) \\
\end{tabular}} & \multicolumn{2}{|r|}{ Recreational facilities } & \multirow[b]{2}{*}{\begin{tabular}{|l}
\multicolumn{1}{|c|}{ Specially protected areas } \\
336 specially protected areas: \\
nature reserves (Orenburg Shaytan-Tau), \\
national parks \\
(Buzuluk Bor), \\
nature reserves ("Svetlin", "Karagay- \\
Guberlin gorge", "Guberlin mountains"), \\
330 natural monuments
\end{tabular}} \\
\hline & $\begin{array}{l}\text { Nauruzum, Tersek, } \\
\text { Amankaragay pine } \\
\text { forests, lakes } \\
\text { (Kushmurun, } \\
\text { Saryoba), Turgay hot } \\
\text { springs, Turgay } \\
\text { geoglyphs, } \\
\text { Karatomar reservoir }\end{array}$ & & & $\begin{array}{l}\text { Landscapes of the southern Urals, } \\
\text { mountain objects, group of lakes Sol- } \\
\text { lletsk (Razval, Tuzluchoye, Dunino, } \\
\text { Novoye, Bolshoye and Maloye } \\
\text { Gorodskoye), Iriklin reservoir, floodplain } \\
\text { of the Ural river, Talov steppe, Burtin } \\
\text { steppe, Aytuar steppe, Ashchisay steppe }\end{array}$ & \\
\hline & $\begin{array}{l}\text { Lake Imantau, and } \\
\text { Shalkar, Maybalyk, } \\
\text { Olkhov forest } \\
\text { cottage, Ayutas the } \\
\text { hill, Bear stone, } \\
\text { Sergeev reservoir }\end{array}$ & $\begin{array}{l}\text { part of the state national } \\
\text { Park "Kokshetau", } 4 \\
\text { reserves: Smirnov, } \\
\text { Sogrov, Mamlyut, } \\
\text { Orlinogor }\end{array}$ & & $\begin{array}{l}\text { Landscapes of the southern Urals, } \\
\text { mountain objects (Ilmen Mountains, } \\
\text { Allaks), caves (Kiselev, Kurgazak, } \\
\text { Sikiyaz-Tamak complex), lakes } \\
\text { (Turgoyak, Zyuratkul, Itkul), coniferous } \\
\text { and mixed forests (Karagay, Shershnev) }\end{array}$ & $\begin{array}{l}\text { Over } 200 \text { specially protected areas: } \\
\text { Nature reserves (Ilmen, Arkaim, East } \\
\text { Ural, South Ural), national parks: } \\
\text { Zaratkul, Taganay; 23 nature reserves; } \\
183 \text { natural monuments }\end{array}$ \\
\hline & \multirow{5}{*}{$\begin{array}{c}\text { Zhasybay Lake, } \\
\text { Sabyndykol, } \\
\text { Toraigyr, } \\
\text { Birzhankol, stone } \\
\text { figures (Kempirtas, } \\
\text { Nayzatas, etc.), } \\
\text { caves (Konyr- } \\
\text { Auliye, Auliye, } \\
\text { grotto of Dravert), } \\
\text { the slopes of } \\
\text { Myrzashoky, } \\
\text { springs } \\
\text { (Auliyebulak, } \\
\text { Teleubulak), gorge } \\
\text { (Aymanbulak, } \\
\text { Stone wonders, } \\
\text { Rakhay, Ushsala), } \\
\text { Shalday, } \\
\text { Beskaragay belt } \\
\text { forests, curative } \\
\text { mud lake Moyyldy, } \\
\text { Lake Maraldy, } \\
\text { floodplain of the } \\
\text { river Yertis }\end{array}$} & \multirow{5}{*}{$\begin{array}{l}\text { Bayanaul national Park, } \\
\text { Kyzyltau nature } \\
\text { reserve, state forest } \\
\text { nature reserve "Yertis } \\
\text { Ormany", } \\
\text { Paleontological nature } \\
\text { monument "Gusinyy } \\
\text { perelet", Natural state } \\
\text { reserve "Floodplain of } \\
\text { the Irtysh river" }\end{array}$} & & $\begin{array}{l}\text { Mountain landscapes of Altai, lakes (Telets, } \\
\text { Kulundin, Bolshoye and Maloye Yarovoye, } \\
\text { Malinovoye, Peschanoye, Bolshoye } \\
\text { Topolnoye, Kuchuk Tanatar, Mormyshan, } \\
\text { Gorkoye, Gorkoye-Peresheyechnoye, } \\
\text { Zavyalov); reference landscapes of relict } \\
\text { ribbon pine forests (Barnaul, Kasmalin), } \\
\text { various hunting and fishing grounds; } \\
\text { mineral healing springs of Belokurikha, } \\
\text { caves (Denisov, Tavdin, Muzeynaya), } \\
\text { cascades of waterfalls (river Shinok, } \\
\text { Peshcherskiy), rock formations } \\
\text { (Tserkovka, Chertov palets, Shlyapnaya) }\end{array}$ & $\begin{array}{l}112 \text { specially protected areas: } \\
\text { reserve "Biosfera", "Tigirek", "Katun", } \\
\text { national parks "Salair", "Aya" and } \\
\text { "Predgorye Altaya", "Belukha", } \\
\text { "Saylyugem", "Uch-Enmek"; } \\
38 \text { nature reserves (Kulundin, Lebedin, } \\
\text { Sumultin, Shavlin, Aleus and Zavyalov), } \\
72 \text { natural monuments (waterfall } \\
\text { "Avrora", mount Semipeshchernaya with } \\
\text { a cave Mrachnaya, Babyrgan, Sinyukha, } \\
\text { Strashnaya cave, Yashchur cave, Chetyre } \\
\text { Brata rock, Shimolin bor, etc.) }\end{array}$ \\
\hline & & & & $\begin{array}{l}\text { lipnyak Baksheyev, floodplain of Ertis } \\
\text { lake, Esil, Bolshaya Tava, Bicha, } \\
\text { Bolshoy Uvat, lakes (Yebargul, Tatyn, } \\
\text { Svyatoye), mixed aspen-birch forests, } \\
\text { pine forests }\end{array}$ & $\begin{array}{l}\text { national park "Ptichya Gavan", } \\
\text { Batakovo, } 16 \text { nature reserves (Bairov, } \\
\text { Stepnoy), more than } 100 \text { natural } \\
\text { monuments (Bereg Dravert, Pyat ozer, } \\
\text { Petropavl pine forest, etc. }\end{array}$ \\
\hline & & & & $\begin{array}{l}\text { Pine forests, lakes (Chernoye, Stekleney, } \\
\text { Malyye Donki, Gorkoye, Medvezhye), } \\
\text { peat mud, the flood-plain of Tobol lake, } \\
\text { mineral springs (Shchadrinskoye, } \\
\text { Krasno-Nivinskoye, Kurganskoye) }\end{array}$ & $\begin{array}{l}19 \text { nature reserves (Kurgan, Belozer, } \\
\text { Almenev, Dalmatov), 99 natural } \\
\text { monuments (Lake Murtaza, Tanrykul } \\
\text { swamp, Ryabinovyy Dol, Suyerskiy bor, } \\
\text { Chudo-derevo, Ivanov kamen, etc.) }\end{array}$ \\
\hline & & & & $\begin{array}{l}\text { Therapeutic mineral waters (Ishim, } \\
\text { Chechkin, Pokrov, Shaim, Surgut), } \\
\text { sapropel mud of Siberian lakes, lakes } \\
\text { (Svetloye, Chernoye, Akhmanka, } \\
\text { Bolshoy and Malyy Taraskul) }\end{array}$ & $\begin{array}{l}38 \text { nature reserves "Tyumen", "Belozer", } 58 \\
\text { natural monuments (Yuzhakovskiy, Sistema } \\
\text { Chernokovskikh ozer, Ozernyy, Marino } \\
\text { ushchelye), wetlands of international importance } \\
\text { "lakes of the Tobol-Iset forest-steppe" }\end{array}$ \\
\hline & & & & $\begin{array}{l}\text { The Salair ridge, boreal spruce-pine forests } \\
\text { (Kashlam bor, Kudryashov, Suzun), birch } \\
\text { groves, lakes (Chany, Krasnozernoye, } \\
\text { Gorkoye, Ostrovnoye, Serebryanoye), } \\
\text { radon water, mineral water (Karachi, } \\
\text { Dovolen, Duplen), the cave (Barsukovskaya, } \\
\text { Yegoryevskaya), Belov waterfall }\end{array}$ & $\begin{array}{l}\text { Part of the Vasyugan nature reserve, } 27 \\
\text { nature reserves (Kazatov, Mangazer, } \\
\text { Manuylov, Chanov), more than } 80 \\
\text { natural monuments ("Volchya griva", } \\
\text { "Dendrologicheskiy park", "Berdskiye } \\
\text { skaly", "Bugotakskiye sopki", } \\
\text { "Chernevyye lesa Salaira") }\end{array}$ \\
\hline
\end{tabular}

The majority of recreational activities of the population is reduced to recreation within or near the place (region) of permanent residence, and short-term outside trips for recreational and tourist purposes. In this regard, the main attention should be paid to the study of local and regional natural recreational resources, their availability, suitability and degree of favorability to meet the recreational needs of the population (Mazhitova et al., 2018). In the border regions of Kazakhstan and Russia, a large number of unique natural and recreational facilities are concentrated, as well as a unique network of specially protected natural areas. This is due to the sparsely populated and weak economic development of the border areas. Along the borders are concentrated habitats of many rare species of living organisms, unique ecosystems and landscapes. These territories represent 
an organizational resource for solving environmental problems, as well as help to realize cross-border tourist flows (Shumkina, 2015). Thus, the existing system of nature protection can be considered not only as the most important direction of bilateral cooperation, but also as one of the factors of territorial organization of cross-border tourism (Grudinin, 2016).

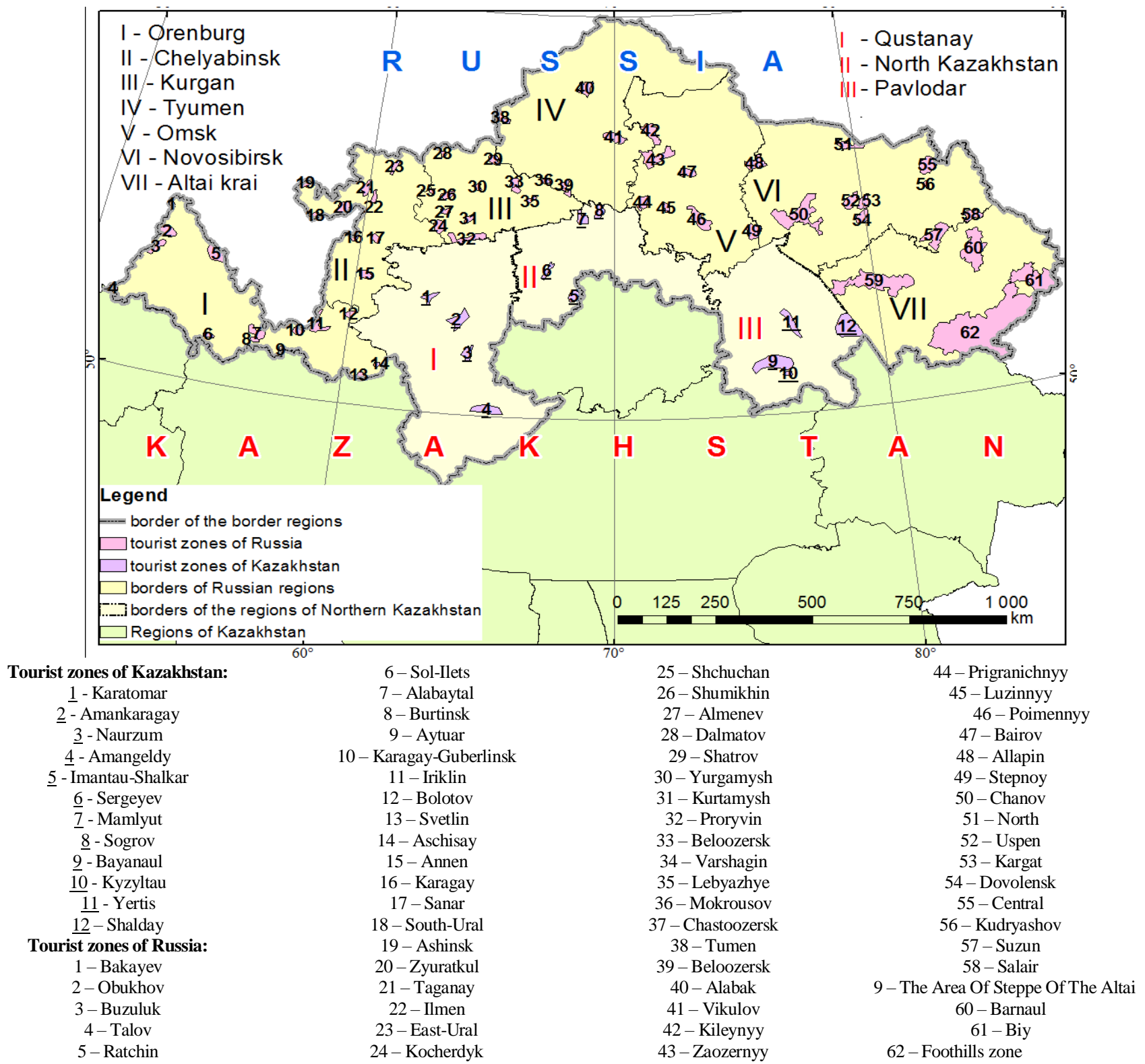

Figure 2. The main tourist zones of the border regions of Kazakhstan and Russia (collected by author)

The study of natural and recreational potential of the study area is composed of a summary table of the main natural recreational resources of the territories that form the tourist attractiveness of regions and can become the links of cross-border cooperation in tourism (table 2). In this case, forest and limnological resources play a special role. When analyzing the data obtained, it was found that there are no lakes with a little recreational capacity among the research water bodies, and only such lakes as Siletyteniz, B.Tavolzhan have low recreational capacity. The remaining water bodies have medium and high recreational capacity (Nazarova et al., 2019). Kazakhstan attracts Russian tourists, as it has a unique natural potential. In Kazakhstan, tourists from Russia are interested in: cultural and educational, environmental, health and business types of tourism. The nature of Northern Kazakhstan is unique and combines unique low-mountain landscapes and boundless steppes, which is favorable and attractive for ecological and health tourism (Stepanov et al., 2020). Since the beginning of 2018, Kazakhstan has been visited by 1.38 million Russians, and Russia by 1.54 million Kazakhstanis. Some experts associate such large volumes not with classical tourism, but with trips of residents of border regions (Kapiki, 2014). And this, in our opinion, further contributes to the increase of tourist flows and strengthening of integration. Based on the data in Table 2, maps of the most visited tourist and recreational zones of the border areas of Russia and Northern Kazakhstan were compiled (Figure 2).

Analyzing the map of tourism areas of border regions of Kazakhstan and Russia to be one of the largest centers of tourism and recreation located in Altai Krai, which was obviously due to natural resource potential and unique landscapes of the Altai Mountains. You can also note the Novosibirsk region. Speaking about Kazakhstan's regions, it is necessary to highlight Pavlodar region, where Bayanaul national nature park is particularly distinguished by its landscape diversity. Given the current ecological 
situation in the industrially developed regions of Northern Kazakhstan and the border regions of Russia, especially such major hubs of heavy industries as Chelyabinsk, Magnitogorsk, Orenburg, Omsk and others, as well as industrial centers of Kazakhstan, such as Kostanay, Pavlodar, special attention should be paid to the development of cross-border eco-tourism (Statistics, 2018). The ever-increasing demand for eco-tourism leads to the creation and development of specially protected natural areas, primarily nature reserves, national and natural parks. Currently, these territories are the main objects of ecotourism in the world (Bancerova and Kasimova, 2018). The existing system of specially protected natural areas plays a key role in the preservation of the country's biological diversity and the development of regulated tourism. Giving a special legal status to these natural objects indicates their uniqueness, as well as a high degree of tourist attraction. In connection with the above, a map has been compiled that reflects the share of the area of specially protected natural areas from the total area of the region (Figure 3 ). However, the presence of specially protected areas does not yet indicate a proper environmental policy of the country. It can be stated that nature conservation in the CIS countries is still insufficiently developed. This is confirmed by the fact that nature reserves occupy a very small share of the total area of the States. Thus, the area of specially protected areas is $8.7 \%$ in Kazakhstan and $12 \%$ in Russia. This is even less than the share of specially protected areas in developing Latin American countries (Pitrakov, 2013).

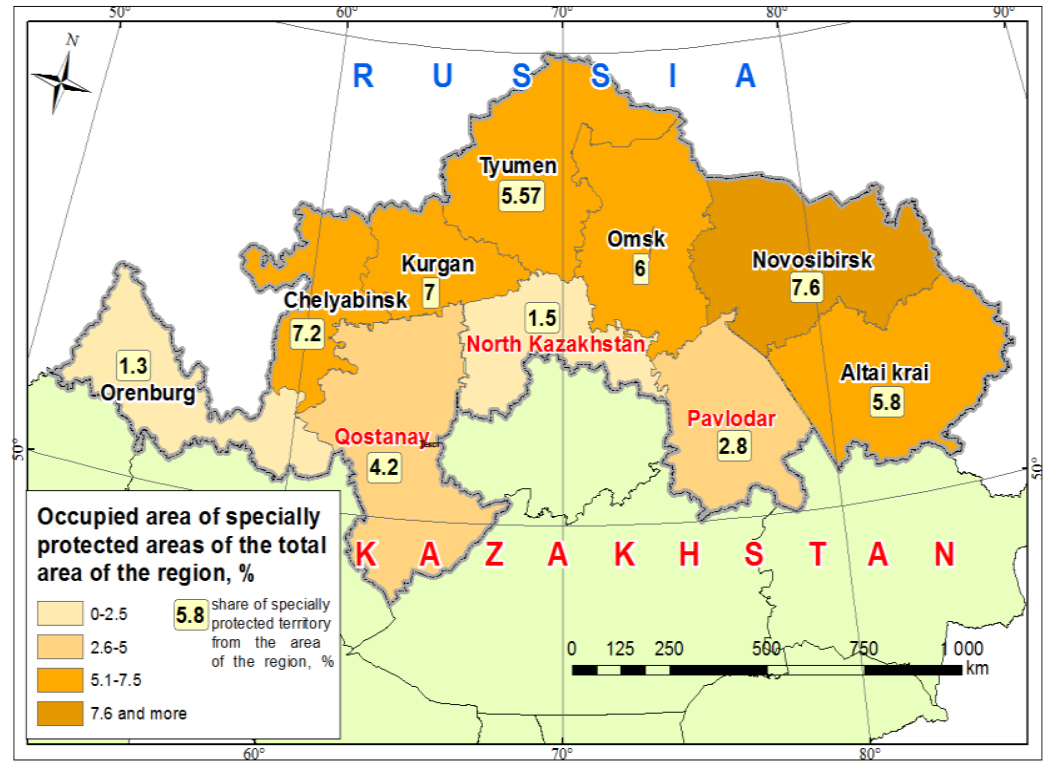

Figure 3. Share of the area of specially protected natural territories from the total area of the border regions of Kazakhstan and Russia (collected by author)

According to the map, the largest share of the area of specially protected areas from the total area of the region is observed in the Novosibirsk region $(7.6 \%)$, the smallest value - in the Orenburg region (1.3\%). Cross-border cooperation in the field of tourism is joint administrative, technical, economic and cultural activities to strengthen and develop goodneighborly cooperation between neighboring States and the conclusion of appropriate agreements to resolve problems that may arise in the tourism sector. For these purposes, a large number of meetings, seminars, international tourism exhibitions, conferences with the participation of representatives of the tourism and hospitality industry are held, exchange internships of specialists in the field of tourism, advertising tours are organized, new joint tourist routes are developed information, advertising and other materials are exchanged in order to familiarize the parties with existing tourist routes (Mirzekhanova, 2014).

\section{Strengths}

- favorable economic and geographical location (border with the Russian Federation); availability of unique natural and cultural monuments for the development of cultural and educational tourism;

- high natural resource potential;

- availability of specially protected areas;

- targeted regional policy and integration of tourism market entities in order to increase the competitiveness of the tourism industry in the region;

- development of cooperation with Russian border regions;

- high export potential of the region;

- availability of opportunities for clustering in the tourism sector;

- high level of mutual demand for goods produced in Kazakhstan and Russia Opportunities

- activation of integration processes within the framework of the EurAsEC, the Customs Union and the Common economic space;

- special attention is paid to the development of the transport system and logistics services in the region;

- expansion of the market in connection with the integration of the EAEU, easing the conditions for the export and import of goods and services;

- improving integration links between industrial enterprises and transport in border regions;

- development of the potential of transport links along the Ertis river with the border regions;

- opportunities for the formation and development of cross-border routes;

- opportunities for the development of ecotourism and hunting and trophy tourism in the region

\section{Weaknesses}

- low level of service in the tourism sector;

- mismatch of prices on the level of quality of tourist services;

- low level of tourist and transport infrastructure, including poor condition of roads leading to tourist sites;

- insufficient level of development of the scientific base of tourism;

- insufficient development of infrastructure in the tourism industry;

- insufficient development of border infrastructure;

- in the development of infrastructure, the neighboring situation with large advanced industrial and transport hubs (Novosibirsk, Chelyabinsk, Ekaterinburg) can have a negative impact);

- insufficient marketing activities to promote tourism potential in the region;

- insufficient development of tourist and transport infrastructure;

- insufficient volume and inconsistency of statistical material for analytical and predictive activities.

- complicated sanitary-epidemiological situation in the world and the regions in connection with pandemia coronaviruses infection

Table 3. SWOT analysis of tourism development and integration of Northern Kazakhstan and Russian border regions

One of the most important and fundamental activities in the framework of cross-border cooperation is the organization and holding of annual international forums. The most ambitious ones include: $\mathrm{X}$ forum of cross-border cooperation within the 
framework of integration associations (Ekaterinburg, November 9-10, 2013), XV forum of interregional cooperation between Russia and Kazakhstan "New approaches and trends in the development of tourism in Kazakhstan and Russia" (Petropavlovsk, November 9, 2018), XVI Forum of cross-border cooperation between Russia and Kazakhstan (Omsk, September 17, 2019) etc.

The most extensive opportunities in the development of tourism in the field of recreational tourism are provided by the natural potential of the border regions of Russia and Kazakhstan, primarily Northern Kazakhstan and the Altai Krai. For the Altai Krai, the Republic of Kazakhstan is the closest and largest foreign trade partner. Every year, representatives of the tourist community of Pavlodar region actively attend tourist events of the Altai Krai, including the international tourist forum "VISIT ALTAI", the holiday "Altai zimovka", the international youth management forum "Altai. Tochki Rosta" (Program, 2014). In turn, the delegation of the Altai Krai regularly takes part in the Kazakhstan International Tourism exhibition Astana Leisure (NurSultan city). In order to get acquainted with the tourist and recreational and health-improving potential of the regions, media representatives of Kazakhstan and Russia regularly participate in information tours (October 15-19, 2018 within the framework of the IV Siberian international forum on health and medical tourism (Barnaul, Belokurikha). In the course of active cooperation of border regions concluded memorandums of cooperation for the development of tourism and resort activities, which aim at strengthening regional cooperation in the sphere of tourism and resort business. This serves as a basis for the implementation of joint projects in the field of cross-border cooperation, exhibition activities, and the development of tourist routes.

Thus, considering various aspects for the development of cross-border tourism in the regions of Kazakhstan and Russia, it is advisable to identify competitive advantages and prospects, as well as disadvantages and problems in this area (Table 3).

\section{CONCLUSION}

Transboundary territories have a special appeal, which can be used for the development of integration processes. Open and accessible borders are part of the tourist potential of the territory. Tourist arrangement of borders can contribute to the economic development of border areas. Increasing the transparency of borders can significantly increase the scale of crossborder tourism. The process of opening borders has become an impetus for the development of tourism in the areas adjacent to the state border, if it is accompanied by economic and social changes (it contributes to the mobility of the population, including in tourist trips). But unfortunately, the problems of tourist formalities in solving integration processes have not been fully resolved. It should be noted that the process of integration of the Russian and Kazakh tourist market into the world is still happening spontaneously, without a single organizational and economic mechanism. The most effective step on this path can be the development of tourism in border regions through the formation of border tourism and recreation clusters. In addition, similar physical and geographical conditions and resource factors, in turn, contribute to mutually beneficial cooperation, strengthening economic integration between states. At this stage of integration cooperation, activities are being carried out to develop the tourist infrastructure of Kazakhstan and Russia within the framework of the EAEU, which also serves as the basis for the development and implementation of cross-border tourist routes.

The natural and recreational potential of the border of Northern Kazakhstan and Russia has sufficient resources for various types of tourism and recreation, in particular such regions as the Altai Krai, Novosibirsk, Kurgan, Orenburg regions of the Russian Federation, Pavlodar and North Kazakhstan regions of the Republic of Kazakhstan.

The key role in the development of cross-border tourism is played by the objects of the nature reserve Fund. These objects represent the landscape diversity of the entire tourist zone. However, tourist activity on them is extremely poorly developed. Tourist routes for most of them exist only in projects, infrastructure facilities are concentrated in visit centers and field hospitals. The share of nature reserves is very small, both in Russia and in Kazakhstan. The lowest rates in this aspect are traced in the Orenburg and North Kazakhstan regions, the average for the entire border area is $4.8 \%$.

The geography of natural and recreational facilities and natural and recreational resources in the development of economic integration of border areas can serve as a solid foundation for the further deepening of integration processes between regions only in the case of competent and balanced nature management and coordination of common efforts in this direction.

\section{REFERENCES}

Akhaev, A. (2019). Predposylki razvitiya prostranstvennoi integratsii transgranichnykh regionov Rossii $i$ Kazakhstana [Background of the development of spatial integration of transboundary regions of Russia and Kazakhstan]. Khumanitarni Balkanski izsledvaniya. V.3, 4(6) (in Russian). https://doi.org/10.34671/SCH.HBR.2019.0304.0009

Aliyeva, S., Chen, X., Yang, D., Samarkhanov, K., Mazbayev, O., Issanova, A., Kozhokulov, S., \& Sekenuly, A. (2019). The socioeconomic impact of tourism in East Kazakhstan Region: Assessment approach. Sustainability (Switzerland), 11(17). https://doi.org/10.3390/su11174805

Aliyeva, Z., Assipova, Z., Bazarbekova, M., Mussagaliyeva, A., \& Sansyzbayeva, A. (2019). Urban area planning and environment in Kazakhstan's cities: Case of Almaty. International Multidisciplinary Scientific GeoConference Surveying Geology and Mining Ecology Management, SGEM, 19(5.2), 775-782. https://doi.org/10.5593/sgem2019/5.2/S20.097

Baklanov, P.Y., \& Ganzei, S.S. (2008). Transgranichnye territorii: problemy ustoichivogo prirodopolzovaniya [Transboundary territories: problems of sustainable nature management], Izdatelstvo Dalnauka, Vladivostok, Russia.

Baklanov, P.Y. (2018). Strukturnye osobennosti i potentsial razvitiya prigranichnykh i transgranichnykh raionov: teoreticheskie aspekty [Structural features and potential of border and transboundary areas development: theoretical aspects]. Regionalnye issledovaniya. 3(6), 19-24 (in Russian).

Bancerova, O.L., \& Kasimova, A.R. (2018). Formation of ethnocultural tourism clusters in Russia-Kazakhstan borderline territory. Journal of Environmental Management and Tourism, 9(4), 771-776. https://doi.org/10.14505/jemt.v9.4(28).10

Bozhko, L.L. (2014). Rossiisko-kazakhstanskoe prigraniche: sovremennoe sostoyanie i problemy razvitiya [Russian-Kazakh border areas: current status and development problems]. Voprosy upravleniya. 3(28), 103-109 (in Russian).

Bozhko, L.L. (2016). Predposylki razvitiya industrialnogo turizma v prigraniche. Turizm kak faktor regionalnogo razvitiya [Prerequisites for the development of industrial tourism in the border region. Tourism as a factor of regional development]. IV Mezhdunarodnaya nauchno-prakticheskaya konferentsiya. 16-22 (in Russian).

Chashina, B., Ramazanova, N., Atasoy, E., Berdenov, Z., \& Ilieș, D.C. (2020). Natural recreation potential of the West Kazakhstan region of the Republic of Kazakhstan. GeoJournal of Tourism and Geosites, 32(4), 1355-1361. https://doi.org/10.30892/gtg.32424-580 
Dunets, A.N., Ivanova, V.N., \& Poltarykhin, A.L. (2019). Cross-border tourism cooperation as a basis for sustainable development: a case study. Entrepreneurship and sustainability issues, 4, 2207-2215. https://doi.org/10.9770/jesi.2019.6.4(45)

Evstropyeva, O.V. (2009). Transgranichnyi turizm v sopredelnykh regionakh Rossii i Mongolii [Trans-boundary tourism in neighboring regions of Russia and Mongolia], Izdatelstvo Instituta Geografii SO RAN, Russia.

Fedorov, G.M., \& Korneevets, V.S. (2009). Transgranichnye regiony v ierarkhicheskoi sisteme regionov: sistemnyi podkhod [Cross-border regions in a hierarchical system of regions: a systematic approach]. Baltiiskii region. 2, 32-41 (in Russian). https://doi.org/10.5922/2074-9848-2009-2-3

Golunov, S.V. (2005). Rossiisko-kazakhstanskaya granitsa. Problemy bezopasnosti i mezhdunarodnogo sotrudnichestva [Russian-Kazakh border. Security and international cooperation issues], Izdatel'stvo VolGU, Volgograd, Russia.

Grudinin, D.A. (2016). Rekreatsionnyi potentsial Orenburgsko-Kazakhstanskogo transgranichya [Recreational potential of the OrenburgKazakhstan cross-border region]. Voprosy stepevedeniya. 13, 23-28 (in Russian).

Hampton, M.P. (2009). The socio-economic impacts of Singaporean cross-border tourism in Malaysia and Indonesia, University of Kent, Canterbury.

Ilieş, A., Wendt J., Ilieş, D.C., \& Grama, V. (2011). Romanian/Ukrainian borderland (northern sector) typology determined by the administrative territorial units (NUTS 3). Central European Regional policyand Human Geography, 2, 7-13.

Ismagulova, S.M., Dmitriyev, P.S., Dunets, A.N., \& Janaleyeva, K.M. (2020). Tourist relations Kazakhstan with the countries of the commonwealth of independent states at the modern stage. Geojournal of Tourism and Geosites, 31(3), 1146-1152. https://doi.org/10.30892/GTG.31328-551

Issabayev, N.Z., Sadykov, T.S., Seitkazina, K.O., \& Bekmaganbetov, U.Z. (2016). Kazakhstan and Russia: Experience and Prospects of Transfrontier Cooperation (1991-2015). International journal of environmental \& science education, 11(17), 9669-9677.

Kapiki, S., Rakhmetulina, Z., \& Nurgaliyeva, A. (2014). Development of Tourism in the Republic of Kazakhstan. International Journal of Global Ideas, 2, 29-39.

Karatabanov, R.A., Janaleyeva, K.M., \& Pashkov, S.V. (2020). Kazakhstan's multiethnicity: factor of inter-ethnic tension and development of cross-border tourism. GeoJournal of Tourism and Geosites, 29(2), 732-745. https://doi.org/10.30892/gtg.29227-502

Katrovsky, A.P., Kovalev, Y.P., Mazhar, L.Y., \& Shcherbakova, S.A. (2017). Turizm v prigranichnykh regionakh: teoreticheskie aspekty geograficheskogo izucheniya [Tourism in border regions: theoretical aspects of a geographical study]. Baltiiskii region. 1, 113-126 (in Russian). https://doi.org/10.5922/2074-9848-2017-1-7

Korneevets, V.S., Redkin, A.G., Studzieniecki, T., \& Zaitseva, N.A. (2019). Influence of border regions relations on the tourist choices of the population. GeoJournal of Tourism and Geosites, 25(2), 569-579. https://doi.org/10.30892/gtg.25223-381

Kropinova, E.G., Kuznetsova, T.Y., \& Fedorov, G.M. (2020). Regional differences in the level of tourism development in the Russian Federation. GeoJournal of Tourism and Geosites, 32(4), 1330-1336. https://doi.org/10.30892/GTG.32421-577

Matznetter, J. (1979). Border and tourism: Fundamental relations. Tourism and Borders: Proceedings of the Meeting of the IGU Working Group Geography of Tourism and Recreation, Institut für Wirtschaftsund Sozialgeographie der Johann Wolfgang Goethe Universität, Frankfurt, Germany.

Mazhitova, G.Z., Saipov, A.A., Ismagulova, S.M., \& Sansyzbayeva, A.B. (2020). Soltustik Qazaqstan oblysy aleumettik-ekonomikalyq damuynyn geografiyasy [Geography of socio-economic development of North Kazakhstan region], NKU of M.Kozybayev, Kazakhstan.

Mazhitova, G.Z., Pashkov, S.V., \& Wendt, J.A. (2018). Assessment of landscape ecological - recreational capacity of north Kazakhstan region. GeoJournal of Tourism and Geosites, 11(3), 731-737. https://doi.org/10.30892/gtg.23309-323

Mirzekhanova, D.G. (2014). Transgranichnye territorii v razvitii mezhdunarodnogo turizma [Transboundary territories in development of international tourism]. Interkarto. InterGIS. 20, 561-566 (in Russian). https://doi.org/10.24057/2414-9179-2014-1-20-561-566

Nazarova, T.V., Fomin, I.A., Dmitriev, P.S., Wendt, J.A., \& Janaleyeva, K.M. (2019). Landscape and limnological research of lake system of the plain areas of the northeastern borderlands of the Republic of Kazakhstan and assessment of their recreational capacity. GeoJournal of Tourism and Geosites, 25(2), 485-495. https://doi.org/10.30892/gtg.25217-375

Pitrakov, V.Y. (2013). Mezhregionalnye torgovo-ekonomicheskie vzaimootnosheniya Rossiiskoi Federatsii i Respubliki Kazakhstan [Commercial and economic relationship of the Russian Federation and the Republic of Kazakhstan]. Nauka o cheloveke: gumanitarnye issledovaniya. 3(13), 5-9 (in Russian).

Prescott, J.R.V. (1987). Political frontiers and boundaries, Allen and Unwin, London, England. https://doi.org/10.4324/9781315747651

Sansyzbayeva, A.B., Saipov, A.A., \& Dunets, A.N. (2020). Ekonomicheskaya integratsiya kak factor prostranstvennogo razvitiya prigranichnykh regionov Severo-Kazakhstanskoi oblasti i Rossii [Economic integration as a factor of spatial development of the border regions of the North Kazakhstan region and Russia]. Kontseptsii i modeli ustoichivogo innovatsionnogo razvitiya obshchestva. Sbornik statei Mezhdunarodnoi nauchno-prakticheskoi konferentsii. 180-182 (in Russian).

Sereda, N.D. (2014). Transgranichnost kak faktor ehffektivnogo prodvizheniya produkta regiona [Cross-border nature as a factor of effective promotion of the region's product]. Sovremennoe sostoyanie i potentsial razvitiya turizma v Rossii. XI Mezhdunarodnaya nauchno-prakticheskaya konferentsiya. 10-11 (in Russian).

Sharifzadeh, A.E., Khakpoor, B.A., \& Ahadnejad, R.M. (2020). Tourism in border cities: case study from Iran. GeoJournal of Tourism and Geosites, 28(1), 52-66. https://doi.org/10.30892/gtg.28104-451

Shumkina, M.A. (2015). Sovremennoe transgranichnoe sotrudnichestvo Rossiiskoi Federatsii i Respubliki Kazakhstan v sfere turizma [Modern cross-border cooperation between the Russian Federation and the Republic of Kazakhstan in the field of tourism]. Innovatsionnaya nauka. 1(11), 217-220 (in Russian).

Soldatenko, D.G. (2015). Transgranichnye territorii v turizme: teoreticheskie aspekty [Trans-border territories in tourism: theoretical aspects]. Nauka i turizm: strategii vzaimodeistviya. 4(2), 60-65 (in Russian).

Statistics Russia, (2018). Politiko-administrativnaya karta Rossiiskoi Federatsii/Politicheskaya karta mira. [Political and administrative map of the Russian Federation/Political map of the world]. Globusnyi mir, Russia.

Statistics, (2018). Statistical collection "Tourism of Kostanay region 2013-2017”. Kostanay, Kazakhstan.

Stepanov, A., Burnasov, A., Ilyushkina, M., \& Kovalev, Y. (2020). Skrite geografske priložnosti za konvergenco rusko-kazahstanskega mejnega območja. [Hidden geographical opportunities for convergence of Russian-Kazakh border area]. Dela, 2020(53), 97-110. https://doi.org/10.4321/dela.53.97-110

Stepanova, S. (2017). Razvitie turizma v prigranichnykh regionakh Rossii [Development of tourism in the border regions of Russia]. Ekonomika i upravlenie. 1, 17-27 (in Russian). https://doi.org/10.24866/2311-2271/2017-4/17-27

Timothy, D.J. (2001). Tourism and political boundaries, Routledge, London, England. https://doi.org/10.4324/9780203214480

Vardomskiy, L.B., \& Mironenko, N.S. (1982). K probleme izucheniya granits ekonomiko-geograficheskikh sistem. Geograficheskie granitsy [On the problem of studying the boundaries of economic and geographical systems. Geographical boundaries], Izdatelstvo MGU, Russia.

Więckowski, M. (2010). Tourism development in the borderlands of Poland. Geographia Polonica, 83(2), 67-81. https://doi.org/10.7163/GPol.2010.2.5

*** Program, (2014). State program of the Altai Krai “Development of tourism in the Altai Krai" for 2015-2020. Barnaul, Russia. 